Revue bibliographique pour le domaine irano-aryen

\title{
R. J. Van der Spek. «Cyrus the Great, Exiles, and Foreign Gods: A Comparison of Assyrian and Persian Policies on Subject Nations »
}

\section{Astrid Nunn}

\section{OpenEdition} Journals

Édition électronique

URL : http://journals.openedition.org/abstractairanica/42563

DOI : 10.4000/abstractairanica.42563

ISBN : 1961-960X

ISSN : 1961-960X

Éditeur :

CNRS (UMR 7528 Mondes iraniens et indiens), Éditions de l'IFRI

\section{Référence électronique}

Astrid Nunn, «R. J. Van der Spek. «Cyrus the Great, Exiles, and Foreign Gods: A Comparison of Assyrian and Persian Policies on Subject Nations » », Abstracta Iranica [En ligne], Volume 37-38-39 | 2018, document 7, mis en ligne le 10 mars 2018, consulté le 28 septembre 2020. URL : http:// journals.openedition.org/abstractairanica/42563; DOI : https://doi.org/10.4000/abstractairanica 42563

Ce document a été généré automatiquement le 28 septembre 2020.

Tous droits réservés 


\title{
R. J. Van der Spek. « Cyrus the Great, Exiles, and Foreign Gods: A Comparison of Assyrian and Persian Policies on Subject Nations »
}

\author{
Astrid Nunn
}

\section{RÉFÉRENCE}

R. J. Van der Spek. «Cyrus the Great, Exiles, and Foreign Gods: A Comparison of Assyrian and Persian Policies on Subject Nations ", in Michael Kozuh, Wouter F. M. Henkelman, Charles E. Jones, Christopher Woods (eds.). Extraction \& Control: Studies in Honor of Matthew W. Stolper. Studies in Ancient Oriental Civilization 68. Chicago, The Oriental Institute of the University of Chicago, 2014, p. 233-264.

1 La politique religieuse des Achéménides, en particulier celle de Cyrus le Grand, est dans la science moderne aussi positivement éclairée que la politique religieuse des Assyriens l'est négativement. L'A. essaie de la replacer dans un contexte plus large en montrant que la tolérance religieuse est commune dans les sociétés antiques mais qu'elle n'implique pas que les dieux étrangers aient été estimés. Le fameux cylindre de Cyrus est avant tout un document d'autolégitimation. 


\section{AUTEURS}

\section{ASTRID NUNN}

Université de Munich 